\title{
"A VOICE TO TALK ABOUT IT": COSMETOLOGISTS AS STEM EXPERTS IN EDUCATIONAL TECHNOLOGY DESIGN AND IMPLEMENTATION
}

\author{
Michael Lachney [lachneym@msu.edu], Michigan State University, \\ [http://education.msu.edu/search/Formview.aspx?email=lachneym@msu.edu],William Babbitt \\ [babbiw2@rpi.edu],RensselaerPolytechnic Institute,AudreyBennett [agbennet@umich.edu],Ron Eglash \\ [eglash@umich.edu],University of Michigan, United States of America
}

\begin{abstract}
In the U.S. there are steady efforts by governmental and philanthropic organizations to increase the representation of students of colour in science, technology, engineering, and mathematics (STEM). After years of mixed results, researchers and educators have started to question one size fits all notions of broadening participation. An increasing number of projects are challenging universalist assumptions by enrolling the expertise of culturally situated communities of practice in STEM lessons and the educational technologies that support them. While this research shows promising results for improving young people's interest and performance in STEM, there has been little research on how these lessons and technologies might also benefit the communities whose expertise were originally enrolled. This paper details the design of educational technologies that bridge STEM and African American cosmetology. We report on a mixed-methods research project, conducted with a group of predominantly African American cosmetologists. Qualitative and quantitative data were collected to study their attitudes toward STEM before and after working with the technologies. Our results suggest positive changes in the cosmetologists' attitudes. We end with a critical discussion about respecting the knowledge systems of underrepresented communities of practice in educational technology research and development.
\end{abstract}

\section{Abstract in Hungarian}

Az USA-ban a kormányzati és jótékonysági szervezetek folyamatos erőfeszítéseket tesznek a színes bőrű hallgatók arányának növelésére a tudomány, technológia, mérnöktudomány és matematika (STEM) területén. Az évek óta tartó vegyes eredmények hatására a kutatók és pedagógusok kételkedni kezdtek abban, hogy univerzális megközelítéssel emelni lehet ezt az arányt. Egyre több projekt kérdőjelezi meg az egyetemes feltételezéseket azáltal, hogy kulturálisan szituált gyakorlati közösségek szakértelmét vonja be a STEM órákba, és az azokat támogató oktatási technológiákba. Bár a kutatás ígéretes eredményeket mutat a fiatalok érdeklődésének és teljesítményének javításával kapcsolatban a STEM területein, kevés kutatást folytattak arról, hogy ezek az órák és technológiák milyen módon válhatnának előnyére a közösségeknek, amelyek szakértőit eredetileg bevonták. Ez a tanulmány a STEM és az afroamerikai kozmetika között hidat képező oktatási technológiák tervezését részletezi. Beszámolónk alapja vegyes módszertanú kutatási projekt, amelyet egy többnyire afroamerikai szépségápolási szakemberekből álló csoportban végeztünk. Kvalitatív és kvantitatív módszerekkel gyújtöttünk adatokat a STEM területekkel kapcsolatos hozzáállásuk megismerésére az adott technológiák a munkájuk során történt felhasználása előtt és után. Eredményeink a szépségápolási szakemberek hozzáállásának pozitív változásaira utalnak. A tanulmányt az alulreprezentált gyakorlati közösségek tudásrendszereinek az oktatási technológia kutatásában és fejlesztésében történő tiszteletben tartásának kritikus tárgyalásával zárjuk.

Keywords: communities of practice, educational technology, STEM education, refusal 


\section{Introduction}

Despite decades of investments from governmental agencies (e.g. National Science Foundation) and philanthropic organizations (e.g., The Gates Foundation) to broaden the participation of people of colour pursuing science, technology, engineering, and mathematics (STEM) education and entering the workforce, underrepresentation continues to be a persistent issue in the United States (NSB, 2018). Generally, more underrepresented students are pursuing STEM education than in the past, but graduation does not consistently improve (Marx, 2017). Malcom and Malcom-Piqeux (2013) report that when it comes to bachelor degrees in mathematics and statistics, for example, African Americans have gone from 7.1\% of recipients in 2001 to 5\% in 2010 (p.177). Workforce trends are similarly troubling. According to the National Science Board (2018), while Black citizens made up $11.8 \%$ of the U.S. population in 2015, they made up only $4.8 \%$ of those in science and engineering occupations that same year (p.114).

One source of underrepresentation in STEM is shallow pedagogic and curricular offerings. This is especially true for computers in education; schools often have computing technologies available but without rigorous (i.e., deep) implementation (e.g., Margolis et al., 2008). Indeed, the shallow implementation of educational technologies in STEM classrooms often means that they are treated as rewards, reproduce the authority of the teacher, or, as Cuban (2001) puts it, are "oversold and underused". But what does deep technology engagement for STEM education mean in the context of underrepresented communities?

Strategies for enriching and deepening the experiences of underrepresented students cannot simply be additional technology or rigor; nor the surface gloss of adding brown virtual characters and ethnic names to the same old lessons. Acknowledging that access to technology is not enough for overcoming racial inequity and providing deep engagement with technology, there have been some efforts to enrol "communities of practice" (CoP) (Lave \& Wenger, 1991) that are relevant to the lived experiences of students of colour in technology design and implementation. Some initiatives seek to collaborate with CoP to attract students to existing technology education programs such as the FIRST LEGO League (Rosen et al., 2013), while others draw on the expertise of CoP as a central part of design itself (Eglash et al. 2017).

This paper seeks to better understand the relationship between culturally situated CoP and educational technology design and implementation. Specifically, we detail a case study in which African American cosmetologists, professionals in computational modelling, and STEM education researchers were brought together in an effort to support African American participation in STEM fields. In this essay we are specifically interested in answering two questions:

- As a CoP, how do cosmetologists view the use of their STEM expertise in educational technology design?

- Does their view of STEM change as a result of helping with educational technology research and development?

We begin by explaining collaborative efforts between researchers, high school students, and cosmetologists around two culturally responsive educational technology programs: Cornrow Curves and $\mathrm{pH}$ Empowered. These efforts resulted in a professional development workshop for cosmetologists during the spring of 2018. Next, we detail the qualitative and quantitative data collection and analysis methods used to study cosmetologists' perceptions of STEM before and after working with these two technologies. Overall, findings show how cosmetologists' generally positive perceptions of STEM in relation to their professional practices improved. Notable increases were found in cosmetologists' comfort with technology and appreciation for STEM 
education. At the same time, some cosmetologists expressed reservations that they had with the use of their knowledge by university researchers. To understand these reservations and provide other educational technology researchers with strategies for addressing them, we discuss providing opportunities for "refusal" (Patel, 2015) in research and development. We conclude with some ideas about how our findings might be generalized and transferable to other cultural and educative contexts.

\section{Background}

During the summer of 2017 a diverse but predominantly White team of social scientists and technologists at a university in Upstate New York hired three young women, two were African American and one multiracial (ages 14-16), as high school interns to help explore intersections between cosmetology and STEM. They were to identify intersections that could motivate educational technology design. Two of the young women had participated in an after-school program with the same topic the previous school year, and the other had learned about the internship opportunity from her hairstylist. None of them were interested in becoming professional cosmetologists, but they all had familiarity with the profession. To give them a sense of what an intersection between STEM and cosmetology might look like, during the first part of the internship they were exposed to a culturally responsive computing application called Cornrow Curves.

Cornrow Curves is one of a large number of similar online learning modules in a suite of Culturally Situated Design Tools (CSDTs). CSDTs highlight connections between STEM and culture by helping young people explore how STEM concepts are already present in the practices and artefacts of CoP (Eglash et al., 2006). More specifically, CSDTs seek to place indigenous and vernacular cultural practices and designs - "dynamic system[s] of social values, cognitive codes, behavioural standards, worldviews, and beliefs used to give order and meaning to our lives as well as the lives of others" (Gay, 2018; p.6) - at the centre of educational technology design and implementation.

As Lave and Wenger (1991) explain, "A community of practice is an intrinsic condition for the existence of knowledge, not least because it provides the interpretive support necessary for making sense of its heritage" (p.98). CSDTs make explicit STEM content within these historically situated contexts, framing the knowledge and practices of CoP as assets to support the educational process and socio-emotional development. Paris and Alim (2017) caution against a strictly asset-oriented view of culture that risks commodifying it for state-sanctioned ends, arguing for the need to sustain and respect cultural dynamics in and of themselves beyond their use-value to schools. CSDTs further these goals by designing socio-technical environments where computing power works in service of $\mathrm{CoP}$ by reflecting culturally situated identities, traditions, and assets (Eglash et al., 2013; Scott et al., 2015; Lachney, 2017).

As an example, Cornrow Curves (see Figure 1) is a visual programming environment created in collaboration with experts in African and African American hair braiding. Collaborating with these experts over the course of years, during the many iterations of the software, entails what Bennett (2016) calls "ethnocomputational" design. This involves a "translation" process between the language and conceptualization of the braiding by cosmetologists and the language and conceptualization of an algorithm by computer scientists. The result of the translation is called a "heritage algorithm," which Bennett (2016) describes as "the under-utilized computational potential in cultural arts such as African-American cornrows, Native American beadwork, and urban graffiti" (p.593). Similar to the interface of other visual programming environments (e.g. Snap!, Scratch, etc.), users encounter the heritage algorithm of cornrow braiding as an assemblage of "blocks" that can be dragged, dropped, and snapped together in a scripting panel and run to 
produce a visual output (i.e., graphic designs with cornrow braids). The heritage algorithm for cornrow braiding that users reverse engineer is meant to represent a larger pattern of intentional mathematical knowledge (e.g., geometric scaling) in African and African American traditional cultural designs (Eglash, 1999).

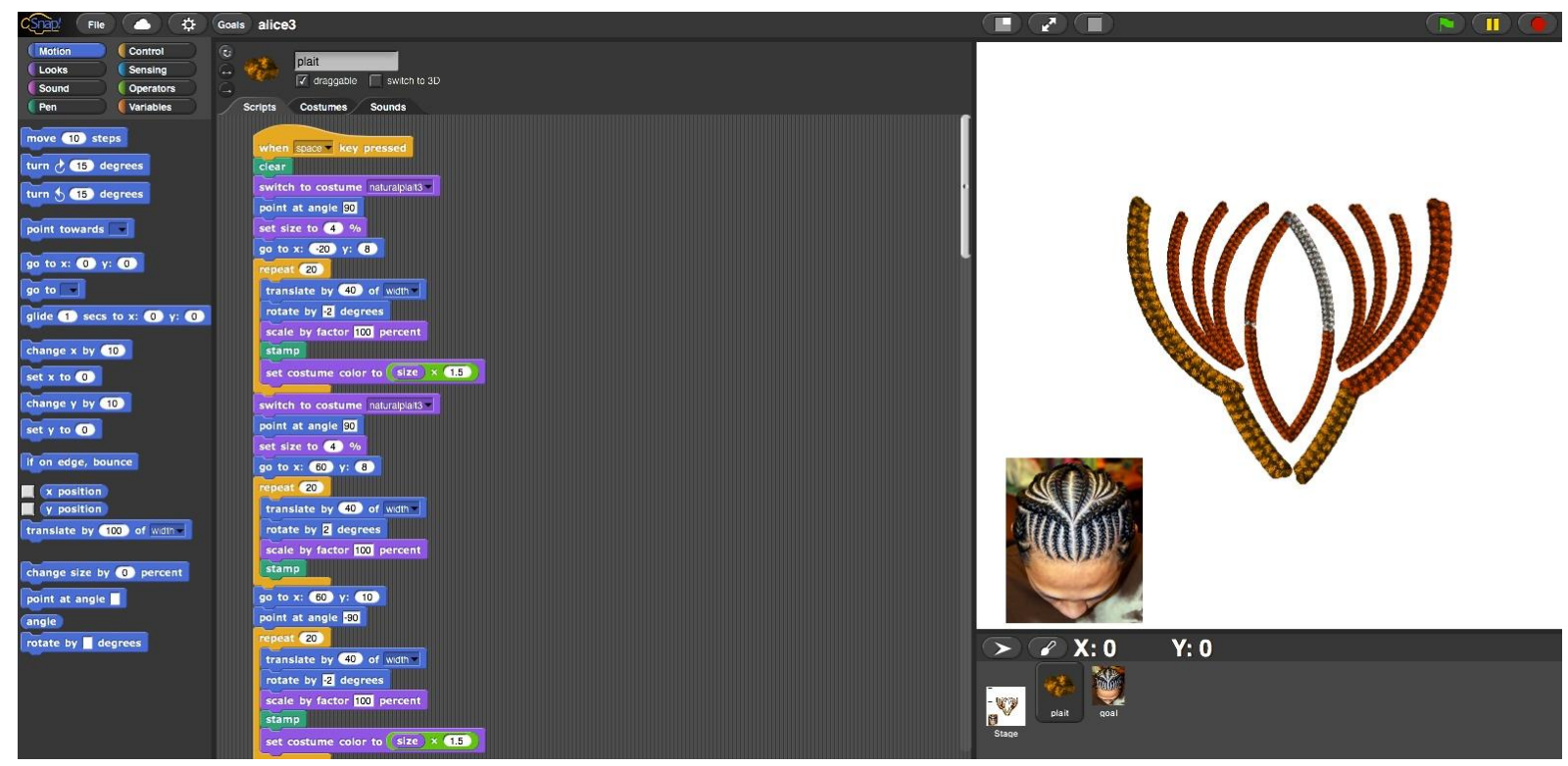

Figure 1. Student created design in Cornrow Curves

After the three interns explored Cornrow Curves and each made a design of their own, they conducted research and brainstormed other possible intersections between STEM and cosmetology. During a presentation to a group of researchers and technologists, they identified $\mathrm{pH}$ as an important aspect of decision-making about what treatments cosmetologists recommend to their clients. Indeed, when applying products to their clients' hair, cosmetologists must know the $\mathrm{pH}$ of different products and balance them to maintain healthy levels (naturally the $\mathrm{pH}$ of hair and skin is between 4.5-5.5). After the presentation, they consulted with an undergraduate in computer science and agreed to spend time learning to build, calibrate, and use a DIY $\mathrm{pH}$ sensor, connected to an Arduino microcontroller (see Figure 2). We would later create a small website around this sensor building activity and call it $\mathrm{pH}$ Empowered, bringing together the politics of Black hair, chemistry, and computing. 


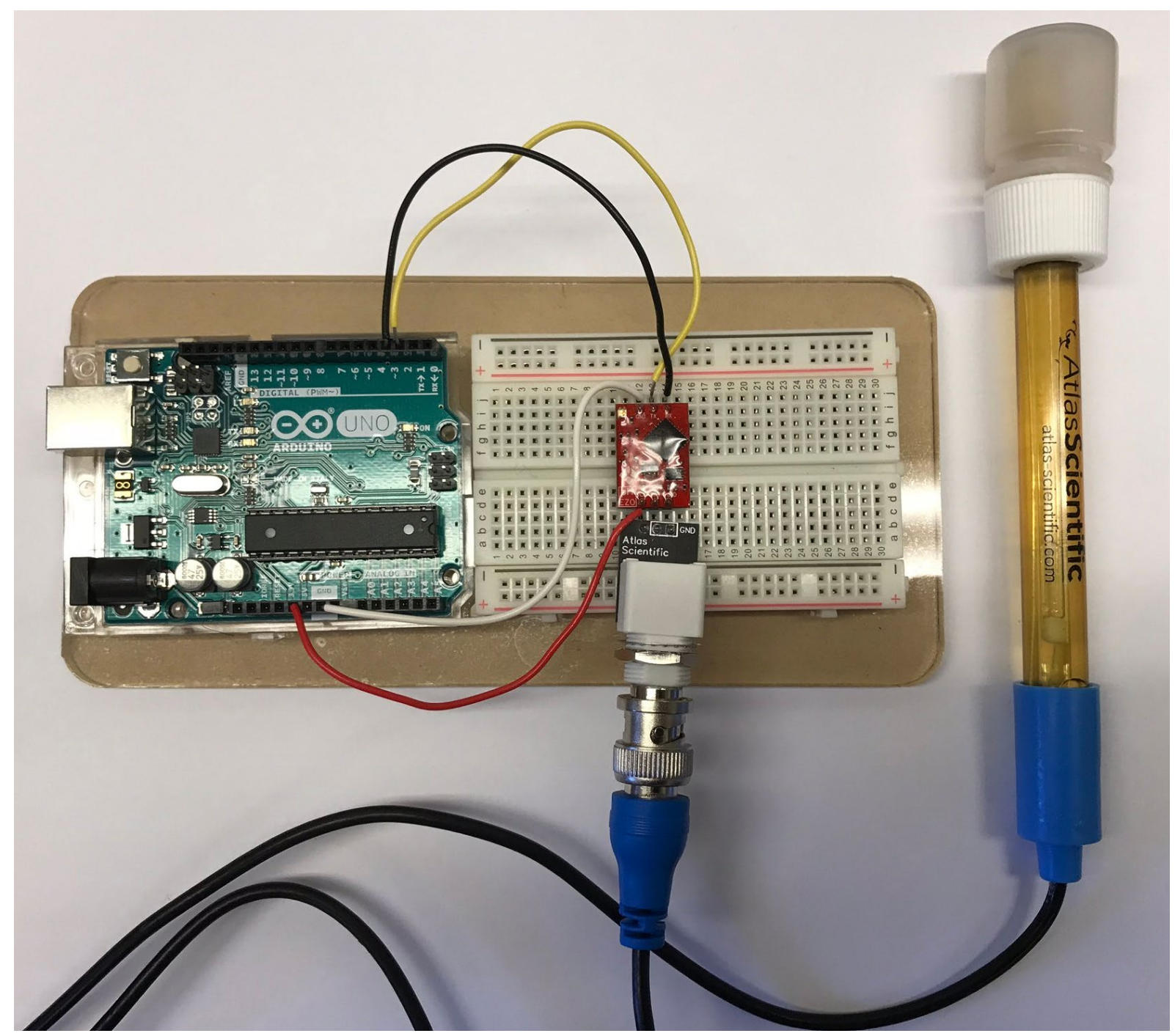

Figure 2. The built $\mathrm{pH}$ sensor using materials for Arduino and the Atlas Scientific pH probe

Later in the month, after the interns were familiar with the technology, we invited two African American women - a high school cosmetology teacher, and the mother of one of the young women and a cosmetologist - to help prepare for an Afrocentric public event in a nearby city. Our goal was to demo Cornrow Curves and $\mathrm{pH}$ Empowered at the event, showcasing both the work of the interns, in addition to highlighting connections between African American cultural capital and STEM. The teacher was enthusiastic about $\mathrm{pH}$ Empowered but offered the critique that the representation of data in the Arduino software did not reflect how students in her class would be exposed to $\mathrm{pH}$, which was with a traditional color-coded and numbered $\mathrm{pH}$ scale from 0 (most acidic) to 14 (most alkaline). What is more, she explained that students in her classes have the most difficulty connecting the increases and decreases in the density of hydrogen and hydroxide ions at different points along the $\mathrm{pH}$ scale. In response, the interns and teacher worked with a computer science undergraduate to develop a $\mathrm{pH}$ visualizer (see Figure 3 ) that would represent the output of data from the $\mathrm{pH}$ sensor along the $\mathrm{pH}$ color-coded numerical scale. Above the scale is a visual indicator for the density of ions, with red dots representing hydrogen ions (more acidic) and blue dots representing hydroxide ions (more alkaline). 


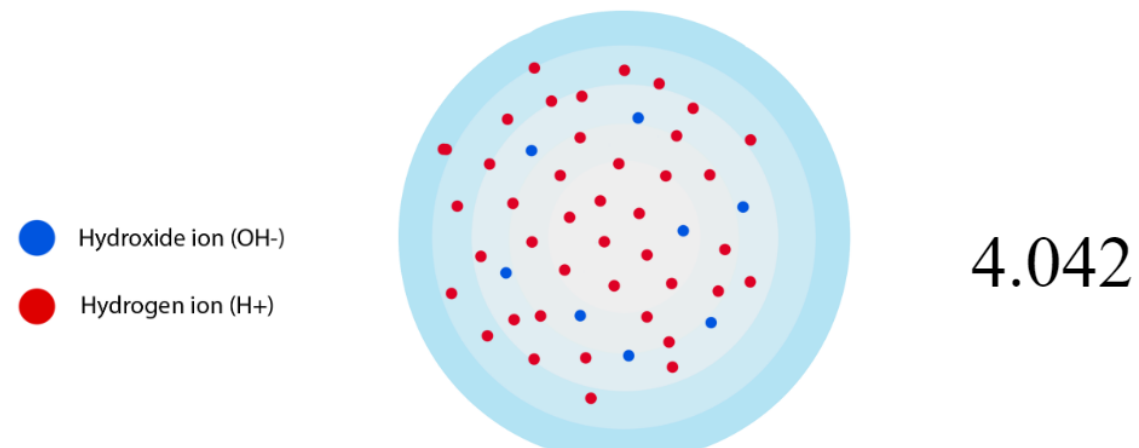

Every time the $\mathrm{pH}$ value increases by 1 , the amount of acid ions decrease by 10 times, and the amount of base ions increase by 10 times. ACIDIC

NEUTRAL

BASIC OR ALKALINE

\begin{tabular}{|c|c|c|c|c|c|c|c|c|c|c|c|c|c|c|}
\hline 0 & 1 & 2 & 3 & 4 & 5 & 6 & 7 & 8 & 9 & 10 & 11 & 12 & 13 & 14 \\
\hline 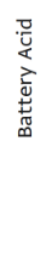 & 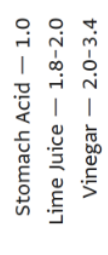 & 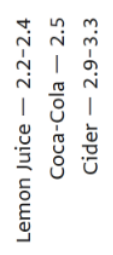 & 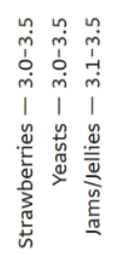 & 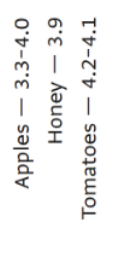 & 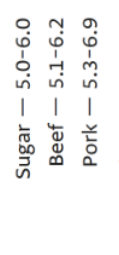 & 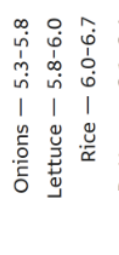 & 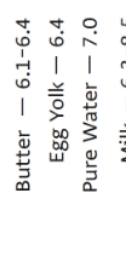 & 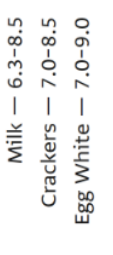 & 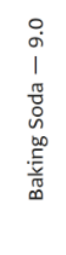 & 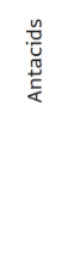 & 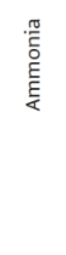 & 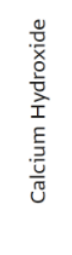 & $\stackrel{0}{د}$ & 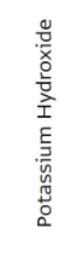 \\
\hline
\end{tabular}

Figure 3. The pH Visualizer

During these preparation sessions, we had the opportunity to learn more about cosmetology by getting to know the teacher and the young woman's mother, who chose the pseudonym of "Nicole" for this paper. We discovered that the interns' focus on $\mathrm{pH}$ had been partially inspired by Nicole's knowledge of chemistry and passion for natural hair care: "Hair that is not chemically altered or strengthened by the pressing comb or blow dryer" (Banks, 2000; p.172). We discovered that Nicole is not only a well-known cosmetologist who makes her own natural cosmetic products but is also a proponent of the natural hair care movement, which seeks to "encourage people to appreciate their own hair texture and the possibilities it offers" (Tarlo, 2016; p.134). Based on her formal and informal education, Nicole uses her knowledge of human anatomy and physiology to educate clients about both natural and chemical hair care, often drawing on her STEM expertise to build trust and rapport.

While collaborating to prepare for the public event, Nicole expressed interest in using her own social capital to help enrol other cosmetologists in culturally responsive educational technology research and development. As a result, a professional development workshop for cosmetologists was arranged for early 2018. Nicole worked alongside researchers and technologists in workshop planning, recruitment, and facilitation. The workshop was used as an opportunity to learn about Nicole's and workshop participants' perceptions of STEM in relation to their own professional practices.

\section{Methods and Participants}

The planning of the cosmetology professional development workshop took place between November 2017 - January 2018, with Nicole and researchers meeting in person, talking over the phone, and exchanging emails. A six-hour workshop was scheduled for a Monday during January 
2018 to take place at a STEM-focused university in Upstate New York. According to Nicole, many cosmetologists where she lives take Mondays off after working part of the weekend. For this reason, we decided that it would be the best day of the week to try and recruit participants. Nicole took on the recruitment responsibilities, advertising primarily through word of mouth and showing up at salons to pass out flyers. The workshop was designed to introduce participants to both Cornrow Curves and $\mathrm{pH}$ empowered, bookended with discussion and reflection periods.

While the workshop was a primary source of data collection, we treated the whole preparation and recruitment process as a research opportunity. Nicole participated in semi-structured preand post-workshop interviews, which were transcribed for analysis. In addition, field notes and audio recordings were taken during preparatory meetings. These data were analysed using a "descriptive" coding technique in which excerpts were summarized with a single word or short phrase to denote the central topic of the text (Saldaña, 2016; p.292). Codes were then organized into three predetermined categories (science and cosmetology; technology and cosmetology; community and cosmetology).

A pre-post survey made up of six sections was created in collaboration with two external evaluators to collect data on workshop participants. The first section provided a space to "please tell us about yourself' by providing information on gender and ethnicity. The next three sections included ten close-ended statements designed to be answered using a six-point Likert-type scale: 1 = Strongly Disagree, 2 = Disagree, 3 = Slightly Disagree, $4=$ Slightly Agree, $5=$ Agree, $6=$ Strongly Agree. Of these, the first five items were intended to measure participants' perceptions about the relationship between cosmetology and science - the next item intended to measure their perceptions of cosmetology as a source of community empowerment. And the last four items were for participants' perceptions of the relationship between technology and cosmetology. The fifth and sixth sections were made up of five open-ended questions about the relationship between cosmetology, STEM disciplines, and community improvement. In addition to the prepost survey, field notes and audio recordings were taken during the workshop, which, along with the open-ended survey questions, were also analysed using descriptive coding and fitted within the three pre-established categories mentioned above.

Altogether nine participants attended the workshop, with most identifying as Black/African American and female (see Table 1). Of the nine attendees, we were able to match pre-post surveys to eight. While ten cosmetologists (i.e., nine workshop attendees and Nicole as the workshop facilitator) is not a large enough " $n$ " to claim statistical significance of any kind, there have been calls in equity-oriented STEM education research to embrace studies with small numbers of individuals. According to Pawley and Slaton (2015), overcoming the stigma of "small $\mathrm{n}$ " studies is an important step to recognizing differences among individuals and destabilizing established assumptions and stereotypes about identity categories (e.g., racial and gender categories). They argue that dismissing small-n research that focuses on already underrepresented identities in STEM can result in further marginalization.

Table 1: Demographic information of professional cosmetology professional development workshop attendees

\begin{tabular}{lccccc}
\hline Gender & $\mathrm{N}$ & Percent & Ethnicity & $\mathrm{N}$ & Percent \\
\hline Female & 7 & 77.8 & Black/African American & 8 & 88.9 \\
Male & 2 & 22.2 & White & 1 & 11.1 \\
\hline
\end{tabular}

Building on the affordances for small-n research to speak to differences in perceptions and experiences within and between groups have an important role to play in strengthening educational technology research on CoP. As Henderson (2015) argues, educational technology 
research needs to be more critical and unromantic about perceived relationships of harmony between education and CoP. Small-n research can aid in these goals by exploring cases where sociocultural activities (e.g., braiding or producing natural cosmetic products) are conceptualized in divergent ways for various means and ends. We triangulated survey, interview, and field note data to give a robust analysis of the different ways that STEM and cosmetology were seen as related by workshop participants. In addition to the three predetermined categories - science and cosmetology, technology and cosmetology, and community and cosmetology - one post hoc category emerged: scepticism. Scepticism appeared in some cosmetologists' precautionary inquiries and reservations about the use of their knowledge by university researchers.

\section{Findings}

Before getting into the specifics, it is important to note that generally, the cosmetologists' perceptions of STEM were positive before and after the workshop. While positive changes were seen in each of the close-ended questions on the post-survey, their pre-survey answers indicate an overall positive view of STEM and its relationship to cosmetology. This is supported by pre-post survey answers to one of the open-ended questions: "please describe how you imagine cosmetology can contribute to improving science, technology, engineering and mathematics (STEM) education." Every answer to this question indicated that cosmetology has clear connections to STEM and many indicated the unique potential of cosmetology to support science teaching and learning. For example, as one participant explained on the pre-survey,

\section{"By proving our knowledge of the makeup of hair and the products we use, one can better understand the relationship between cos [metology] and science. Why we use the things we use, bow it affects you, your skin and how it is composed."}

Similar responses were found in the post-surveys. One slight difference was that more answers mentioned the use of technology to support both education and the salon. For example, "We could contribute to it by testing products out, as well as testing out technology with what we do." As we will see below, the increased attention to technology in post-survey answers is consistent with other findings.

\section{Science and Cosmetology}

Table 2 shows that of the eight matched pre-post surveys, the majority of participants had established positive beliefs about the relevance of science to their profession and its potential to support science education. When asked to "describe what you perceive as the relationship between cosmetology and science," the majority of pre-survey answers drew on anatomy, physiology and/or chemistry terminology to support the connection. For example,

"The composition of the hair and scalp, its breakdown. How things like chemicals and certain conditioners affect your hair and scalp. The inner workings of the body are directly correlated with the hair and scalp."

This is consistent with Nicole's pre-workshop interview, where she describes how using scientific knowledge is not only important for differentiating products and treatments, but also for educating and building rapport with clients:

'Because it's just so important to kind of educate your client also on the science, because it is a science... hair is made out of certain proteins and bonds... they all work together and in a way which a lot of people... don't understand and don't educate themselves, don't realize. And, for me, it's just amazing." 
Given the way that scientific literacies support both the knowledge base of cosmetology and customer relationships, it is not surprising that the connections between cosmetology and science were commonly acknowledged by workshop participants.

Table 2: Pre-post survey answer comparison for science and cosmetology items

\begin{tabular}{|c|c|c|c|}
\hline Statement & $\begin{array}{c}\text { Pre } \% \\
\text { Agree } \\
+ \\
\text { Strongly } \\
\text { Agree }\end{array}$ & $\begin{array}{c}\text { Post \% } \\
\text { Agree } \\
+ \\
\text { Strongly } \\
\text { Agree }\end{array}$ & $\begin{array}{c}\% \\
\text { Change }\end{array}$ \\
\hline $\begin{array}{l}\text { I think that cosmetology and science can mutually support } \\
\text { each other. }\end{array}$ & 87.5 & 100 & +12.5 \\
\hline I feel confident talking about science to my customers. & 75 & 87.5 & +12.5 \\
\hline $\begin{array}{l}\text { I think that young people in my community would benefit } \\
\text { from having more cosmetology in their science courses. }\end{array}$ & 75 & 100 & +25 \\
\hline $\begin{array}{l}\text { I think that understanding chemistry improves the practices of } \\
\text { cosmetologists }\end{array}$ & 75 & 100 & +25 \\
\hline $\begin{array}{l}\text { I would feel confident collaborating with a science teacher to } \\
\text { help deliver a chemistry lesson in the classroom }\end{array}$ & 62.5 & 75 & +12.5 \\
\hline
\end{tabular}

The post-survey answers in Table 2 about their confidence collaborating with teachers and talking about science to customers may be connected to some of the language and ideas communicated during the workshop. While their post-survey open-ended answers tended to be shorter, they all used specific terminology related to $\mathrm{pH}$ : " $\mathrm{pH}$ balance and working with products that affect the hair". It is possible that building the probe, testing products, and discussing their results in collaboration with one another reinforced existing knowledge, but presented it in new ways.

\section{Technology and Cosmetology}

Table 3 suggests that most workshop participants had existing positive attitudes toward the role of computer science in supporting cosmetology. In addition, most indicated confidence in delivering a computing lesson with technology teachers. When asked to "Describe what you perceive as the relationship between cosmetology and computing," they gave a variety of answers for both the pre- and post-surveys, ranging from data storage to mathematically informed artistic rendering and computational sensing. What changed on the post-survey was less focus on the computer for storage and more on its artistic potential and precision:

\section{"I perceive it as measurements \& placements. This could help with knowing where to place color, highlight, braids, dreads. Also knowing about sizing."}

Given Cornrow Curves emphasis on coding visual designs, the workshop activities may have supported the idea that computing can be a bridge between STEM and artistry. Nicole reinforced this in a post-workshop interview,

"... a lot of cosmetologists look at what they do as an art, and that's what it is. They create on someone's head, but still, as a creator, these are still human beings, and they want to have bealthy hair, and sometimes you need to step back away from the art part and understand the science bebind what it is that you are doing." 
The important role of creativity in computing is supported by many computer science education researchers (Papert, 1980; Solomon, 1988; Bennett, 2016; Resnick, 2017), but there has been little research on how creativity might help adults make contact with computer science education inside and outside of formal education environments. And, how might these adult's knowledge of computing support deeper engagement with educational technology for youth?

Table 3: Pre-post survey answer comparison for technology and cosmetology items

\begin{tabular}{|c|c|c|c|}
\hline Statement & $\begin{array}{c}\text { Pre \% } \\
\text { Agree } \\
+ \\
\text { Strongly } \\
\text { Agree }\end{array}$ & $\begin{array}{c}\text { Post \% } \\
\text { Agree } \\
+ \\
\text { Strongly } \\
\text { Agree }\end{array}$ & $\begin{array}{c}\% \\
\text { Change }\end{array}$ \\
\hline $\begin{array}{l}\text { I think that computer science can make an important } \\
\text { contribution to cosmetology }\end{array}$ & 87.5 & 100 & +12.5 \\
\hline $\begin{array}{l}\text { I feel confident using computing technology in my } \\
\text { cosmetology practice }\end{array}$ & 62.5 & 87.5 & +25 \\
\hline $\begin{array}{l}\text { I feel that my customers would benefit from my knowledge of } \\
\text { technology and computing }\end{array}$ & 50 & 100 & +50 \\
\hline $\begin{array}{l}\text { I feel confident in collaborating with a technology teacher to } \\
\text { help deliver a computing lesson in the classroom }\end{array}$ & 75 & 87.5 & +12.5 \\
\hline
\end{tabular}

The most notable changes in Table 3 are with the cosmetologists' answers to questions about their own professional practices and customer relationships. Not only did they indicate more confidence in using technology to support their practice, but also that their customers would benefit from their knowledge of computing. As with the cosmetology teacher's prompt to connect the $\mathrm{pH}$ sensor to a $\mathrm{pH}$ visualizer for helping her students understand ions, part of the creativity in computing is helping people explore what they already know - professional or otherwise - in new ways.

While the workshop participants had a generally positive attitude toward technology's relationship to cosmetology, they also provided important critiques and constructive criticism about Cornrow Curves and $\mathrm{pH}$ Empowered during the workshop. For example, when asked the question we posed to the high school interns the summer before (i.e. how might these technologies support both schools and salons?) workshop participants generally thought it was fine for schools, but feedback for how the technology could support the salon came in the form of new research directions and dynamic technological innovations. One workshop participant who made a multi-colour Cornrow Curves design explained that he thought the program's colour blocks would be useful for "mapping" out hair colour patterns before applying them to customers. At the same time, he stressed the need for representing different head sizes and dimensions as part of the software if it was to be useful for professional practice.

\section{Community and Cosmetology}

As shown in table 4, the participants all agreed or strongly agreed with the sentiment, "I think cosmetology is a source of community empowerment," with no change on the post-survey for this closed-ended question. When asked about their relationship with the larger community in open-ended questions, they framed cosmetology as a source for high self-esteem and confidence. This "empowerment," in their words, comes from their beliefs that "hair in the Black community is a very important aspect in personal happiness," and that cosmetology brings "wellness to your body." As one workshop participant explained, 
"Yes, when someone comes to get their hair done, it is like an emotional fix. Looking good makes people feel good about yourself; you make better decisions. It contributes to morale."

Workshop participants saw themselves as part of a giving or helping profession: "We are a community that is constantly giving back in numerous ways, whether it be a hairstyle or donation."

In addition, some of the post-test answers hint at the position of the barbershop or salon as a community centre for forming interpersonal relationships and networks. For example,

'The salon and barbershop is a staple in the community. People who wouldn't normally interact in everyday life will interact in these settings. It gives us a forum and platform to use to voice new things we have learned to our community."

Indeed, Majors (2015) explains how conversations that happen in hair salons play important roles in exploring problem-solving strategies, developing linguistic literacies, and negotiating cultural norms for many African Americans. The participants in the workshop appeared well aware of this fact.

Table 4: Pre-post survey answer comparison for community and cosmetology items

\begin{tabular}{lccc}
\hline Statement & Pre $\%$ & Post \% & \\
& Agree & Agree & + \\
+ & $\begin{array}{c}+ \\
\text { Strongly } \\
\text { Agree }\end{array}$ & $\begin{array}{c}\text { Strongly } \\
\text { Agree }\end{array}$ & Change \\
\hline $\begin{array}{l}\text { I think cosmetology is a source of community } \\
\text { empowerment }\end{array}$ & 100 & 100 & - \\
\hline
\end{tabular}

In addition to a general sentiment that cosmetology is a source of community empowerment, Nicole and workshop participants also indicated that they appreciated the opportunity to connect with fellow cosmetologists at the workshop. One workshop participant explained his desire to continue future workshops with existing and new participants,

"I think the next group is going to be just like we were, so passionate to finally get a voice to talk about it... This is something we are all gonna talk about in the salon."

Nicole also described a positive experience while recruiting for the workshop, visiting four different salons in the process: "like that was just such a nice day for me". In addition to being able to see different salon spaces, she reconnected to students she had taught in the past and other colleagues in the industry. Some of these connections were maintained after the workshop ended. In a post-interview, Nicole explained,

"...one of the guys, he called me yesterday to ask me a question about something... he was like we have a natural hair stylist in our salon... is it okay if I give her your number because she's young and she's new to this, but she would have really benefited from learning from you."

For these and other reasons, Nicole and the rest of the team felt that the workshop was successful in making these points of contact. At the same time, there were moments of scepticism by some of the workshop participants about the use of Black cosmetology knowledge for educational technology research. 


\section{Scepticism}

The topic of scepticism was brought up during a discussion period early on in the workshop and in one-on-one conversations with White workshop facilitators. Cosmetologists explained to some members of the research team about their experiences working in salons that specialized in serving different clienteles, including those that were primarily Black, primarily White, and multiracial. They urged us, as a research team, to consider who the research was meant to serve and reminded us of the diversity of voices and positionalities in Black cosmetology CoP. We want to take a moment to reflect on what we learned from these expressions of scepticism.

Indeed, listening to and representing the diversity of unified and divergent voices within communities of practitioners is one step toward deepening theorization with $\mathrm{CoP}$ in educational technology research and scholarship. Nicole, the workshop participants, and other cosmetologists have generally approved of Cornrow Curves and $\mathrm{pH}$ Empowered. But what if this was not the case? What if there were aspects of their knowledge (e.g., recipes for natural cosmetics, knowledge that helps them build rapport with clients, etc.) that they were uncomfortable with educational technology researchers using? The obvious answers are that the researchers should respect their collaborators' wishes and make conscious efforts not to represent that community knowledge, practice, or design within their work.

As educational technologies become culturally situated and relevant, drawing on the knowledge of localized CoP in efforts to deepen the STEM experiences for underrepresented students, we believe that there is a need for researchers and technologists to understand the politics of refusal and create opportunities for refusal during design and implementation. Patel (2015) has pointed out that one major problem with social science and education research on and with minoritized communities is the tendency to treat knowledge gathered in the form of data as property. Patel (2015) explains how "communities and individuals, required for social science research as participants, don't have existing systems of redress if they wish to maintain ownership of their knowledges" (p.370). Building on the work of Simpson (2014) and Tuck and Yang (2013), Patel suggests more frequent "refusal" options and mechanisms as one way to confront the embedded ideologies of colonial ownership in social science and educational research. While it would be wrong to assume that there is one framework for refusal - "...all refusal is particular, meaning refusal is always grounded in historical analysis and present conditions" (Tuck \& Yang, 2013; p.243) - the burden of providing opportunities for refusal in educational technology design should be on the researchers.

Refusal opportunities might begin with anonymous options for refusal provided via surveys or be part of interview protocols. One time opportunities for refusal in surveys and during interviews are relatively straightforward. Much more difficult for co-design projects is providing iterative opportunities for refusal throughout the process. In a recursive fashion, this requires codesigning refusal opportunities as part of the co-design of educational technologies. As Tuck and Yang (2013) make clear, these iterative opportunities will need to be historically grounded in ways that make sense to $\mathrm{CoP}$ in the present. Toward this goal, if we aim to deepen theorization of CoP it may be that new methods for community-oriented validity - based on granting and refusing the use of knowledge, practices, and designs - will need to become a necessary component of educational technology research and development. 


\section{Conclusion}

This paper has sought to study the relationships between CoP and educational technology research and development, with specific attention to efforts to broaden the participation of underrepresented communities of colour in STEM fields. Indeed, CoP have become important actors and collaborators in the design of educational technology programs that aim to deepen STEM learning experiences for youth of colour. Despite the growing recognition that CoP are important assets, there has been little research about how members of these communities view the enrolment of their own expertise and practices in educational technology programs. Indeed, this appears to be part of a larger trend in educational technology research where CoP are undertheorized (Henderson, 2015). As a partial course correction, we have sought to answer two questions about our own work collaborating with African American cosmetologists in educational technology design and implementation: As a CoP, how do cosmetologists view the use of their STEM expertise in educational technology design? And, does their view of STEM change as a result of helping with educational technology research and development?

To answer the first question, Nicole and the workshop participants were generally approving and, at times, even excited to support our team in the design and implementation of educational technologies that used cosmetology as a source of expertise and knowledge. Indeed, we learned that cosmetologists are STEM experts in many ways. They see their knowledge-base as informed by STEM disciplines, especially science areas such as anatomy, physiology, and chemistry, and use that knowledge to support their clientele. Given this relationship, it is not surprising to see that workshop participants indicated that cosmetology could be a source of technosocial innovation in STEM education. At the same time, some of the workshop participants were sceptical of our uses of their STEM knowledge for educational technology research and development. In response, we have started a discussion about how opportunities for refusal can be incorporated into co-design research projects.

In response to the second question, we found that while there were positive changes in the majority of post-survey responses, the workshop participants already found strong, positive connections between STEM disciplines and cosmetology. Yet, not all connections were the same. We saw less of a change in survey questions about cosmetology's relationship to science. Indeed, through our more in-depth work with cosmetology education in New York State, we found that knowledge of chemistry, anatomy, and physiology are central to curriculum and licensure requirements. Less central is a focus on technology, reflecting the fact that we saw more positive changes in questions about technology. It may be that Cornrow Curves and $\mathrm{pH}$ Empowered did indeed build on STEM areas that are already important to cosmetology, weaving together technical, creative, and artistic domains. Open-ended questions, group discussions, and interviews suggest that the technologies may have presented these domains, and the connections between them, in new ways.

While this case was specific to African American cosmetology CoP, our educational technology research and development methods are applicable across contexts where increasing the participation of minoritized demographic groups in STEM is prioritized. The innovation of this approach, what Bennett (2016) calls "ethnocomputational" design, is that creative and deep uses of technology build on culturally situated practices and designs to highlight technical and artistic sophistication. In another case of ethnocomputational design, Babbitt et al. (2015) show the wood carving and textile traditions of Ghanaian Adinkra symbols are early examples of using logarithmic curves to model organic growth. Bennett et al. (2016) reveal how including Adinkra artisans in the design and implementation of technologies that highlight this technical and artistic sophistication creates pathways for circulating their knowledge and skills between schools and 
communities. Eglash et al. (2006) argue that doing so respectfully can challenge the myths of genetic determinism and primitivism.

Therefore, co-designing processes with minoritized CoP can work to challenge Eurocentrism in STEM education and professions, while also innovating educational technology research and development. We have sought to make clear that this is a multidirectional process, one where all parties are open to change, including, and perhaps most importantly, those of the researchers and technologists. We hope that other research teams who are interested in building relationships with CoP will learn from our work to develop their own approaches to this multi-directional process, being responsive and historically grounded to both students and the communities where they live.

\section{References}

1. Banks, I. (2000). Hair matters: Beauty, power, and black women's consciousness. New York, NY: NYU Press.

2. Babbitt, W., Lachney, M., Bulley, E., \& Eglash, R. (2015). Adinkra mathematics: A study of ethnocomputing in Ghana. Multidisciplinary Journal of Educational Research, 5(2), 110-135.

3. Bennett, A. (2016). Ethnocompuational creativity in STEAM education: A cultural framework for generative justice. Teknokultura, 13(2), 587-612.

4. Bennett, A., Eglash, R., Lachney, M., \& Babbitt, W. (2016). Design agency: Diversifying computer science at the intersections of creativity and culture. In M. Raisinghani (Ed.), Revolutionizing Education through Web-Based Instruction (pp. 35-56). Hershey, PA: IGI Global.

5. Cuban, L. (2001). Oversold and underused: Reforming schools through technology, 1980-2000. Cambridge, MA: Harvard University Press.

6. Eglash, R., Bennett, A., O Donnell, C., Jennings, S., \& Cintorino, M. (2006). Culturally situated design tools: Ethnocomputing from field site to classroom. American Anthropologist, 108(2), 347-362. https://doi.org/10.1525/aa.2006.108.2.347

7. Eglash, R. (1999). African fractals: Modern computing and indigenous design. New Brunswick, NJ: Rutgers University Press.

8. Eglash, R., Babbitt, W., Bennett, A., Bennett, K., Callahan, B., Davis, J., Drazan, J., Hathawa, C., Hughes, D., Krishnamoorthy, M., Lachney, M., Mascarenhas, M., Sawyer, S., \& Tully, K. (2017). Culturally Situated Design Tools: Generative justice as a foundation for STEM diversity. In P. Tripathi, Y. Rankin, \& J. Thomas (Eds.), Moving Students of Color from Consumers to Producers of Technology (pp. 132-151). Hershey, PA: IGI Global. https://doi.org/10.4018/978-1-5225-2005-4.ch007

9. Gay, G. (2018). Culturally responsive teaching: Theory, research, and practice (3 $3^{\text {rd }}$ ed.). Multicultural education series. New York, NY: Teachers College Press.

10. Henderson, M. (2015). The (mis) use of community of practice: Delusion, confusion, and instrumentalism in educational technology research. In S. Bulfin, N. F. Johnson, \& C. Bigum (Eds.), Critical perspectives on technology and education (pp. 127-140). New York, NY: Palgrave Macmillan.

11. Lachney, M. (2017). Culturally responsive computing as brokerage: Toward asset building with education-based social movements. Learning, Media and Technology, 42(4), 420-439.

12. Lave, J., \& Wenger, E. (1991). Situated learning: Legitimate peripheral participation (Vol. 521423740). Cambridge, UK: Cambridge University Press. 
13. Majors, T. J. (2015). Shoptalk: Lessons in teaching from an African American hair salon. New York, NY: Teacher College Press.

14. Malcom, S. M., \& Malcom-Piqueux, L. E. (2013). Critical mass revisited: Learning lessons from research on diversity in STEM fields. Educational Researcher, 42(3), 176-178.

15. Margolis, J., Holme, J., Estrella, R., Goode, J., Nao, K., \& Stumme, S. (2008). Stuck in the shallow end: Race, education, and computing. Cambridge, MA: MIT Press.

16. Marx, S. (2016). Qualitative Research in STEM: Studies of Equity, Access, and Innovation. New York, NY: Routledge.

17. National Science Board (2018). Science \& Engineering Indicators 2018. Arlington, VA: National Science Foundation. Retrieved November 26, 2018, from https://www.nsf.gov/statistics/2018/nsb20181/

18. Papert, S. (1980). Mindstorms: Children, Computers, and Powerful Ideas. New York, NY: Basic Books.

19. Paris, D., \& Alim, H. S. (2017). Culturally sustaining pedagogies: Teaching and learning for justice in a changing world. New York, NY: Teachers College Press.

20. Patel, L. (2015). Countering coloniality in educational research: From ownership to answerability. Educational Studies, 50(4), 357-377.

21. Pawley, A. L., \& Slaton, A. E. (2015, June). The Power and Politics of STEM Research Design: Saving the 'Small N'. Paper presented at 2015 ASEE Annual Conference \& Exposition, Seattle, Washington. doi: 10.18260/p.24901

22. Resnick, M. (2017). Lifelong kindergarten: Cultivating creativity through projects, passion, peers, and play. Cambridge, MA: MIT Press.

23. Rosen, J. H., Newsome, A., \& Usselman, M. (2011, June). Promoting Diversity and Public School Success in First Lego League State Competitions. Paper presented at 2011 ASEE Annual Conference \& Exposition, Vancouver, BC. Retrieved from https://peer.asee.org/18880

24. Saldaña, J. (2016). The Coding Manual for Qualitative Researchers (3 ${ }^{\text {rd }}$ ed.). Los Angeles, CA: SAGE Publications.

25. Scott, K. A., Sheridan, K. M., \& Clark, K. (2015). Culturally responsive computing: A theory revisited. Learning, Media and Technology, 40(4), 412-436.

26. Simpson, A. (2014). Mohawk interruptus: Political life across the borders of settler states. Durham, NC: Duke University Press.

27. Solomon, C. (1988). Computer environments for children: A reflection on theories of learning and education. Cambridge, MA: MIT Press.

28. Tarlo, E. (2016). Entanglement: The secret lives of hair. London, UK: Oneworld Publications.

29. Tuck, E., \& Yang, K. W. (2014). R-Words: Refusing Research. In Paris, D., \& Winn, M. T. (Eds.), Humanizing Research: Decolonizing Qualitative Inquiry with Youth and Communities (pp. 223247). Los Angeles, CA: SAGE Publications.

\section{Acknowledgement}

This work was supported by the National Science Foundation grant \#1640014 and Rensselaer Polytechnic Institute. The views and opinions expressed in this work do not necessarily represent those of NSF or RPI. 